\title{
PERANAN LINGKUNGAN PENDIDIKAN SEKOLAH TERHADAP MOTIVASI BELAJAR BIDANG STUDI EKONOMI PADA MATERI POKOK PENDAPATAN NASIONAL PESERTA DIDIK DI KELAS X SMA NEGERI 1 SAYURMATINGGI TAHUN PELAJARAN 2016-2017
}

\author{
${ }^{(1)}$ Wulan Sari Agustina dan ${ }^{(2)}$ Riski Baroroh \\ (1) Mahasiswa FKIP Universitas Muhammadiyah Tapanuli selatan \\ ${ }^{(2)}$ Dosen FKIP Univeristas Muhammadiyah Tapanuli Selatan
}

\begin{abstract}
Abstrak
Jenis penelitian yang digunakan dalam penelitian ini adalah penelitian asosiatif yaitu penelitian yang bertujuan untuk mengetahui apakah ada hubungan antara dua variabel atau lebih. Teknik pengumpulan data dilakukan dengan penyebaran angket dan test kepada peserta didik sebagai sampel penelitian. Selanjutnya untuk menguji hipotesis digunakan rumus korelasi product moment:

$$
r_{x y}=\frac{N \Sigma X Y-(\Sigma X)(\Sigma Y)}{\sqrt{\left\{N \Sigma X^{2}-(\Sigma X)^{2}\right\}\left\{N \Sigma Y^{2}-(\Sigma Y)^{2}\right\}}}
$$

Berdasarkan analisis data yang dilakukan melalui korelasi product moment maka diperoleh nilai $r_{\text {hitung }}$ 0,887, dan nilai $r_{\text {tabel }}$ 0,227 taraf kesalahan 5\% dengan $N=75$. Dari nilai tersebut dapat dilihat bahwa rhitung lebih besar dari pada $r_{\text {tabel }}$ yaitu 0,887 > 0,227 maka dapat dikatakan bahwa Ada Peranan Lingkungan Pendidikan Sekolah Terhadap Motivasi Belajar Bidang Studi Ekonomi Pada Materi Pokok Pendapatan Nasional Peserta Didik Di Kelas X SMA Negeri 1 Sayurmatinggi Tahun Pelajaran 2016-2017.
\end{abstract}

Kata Kunci: Peranan Lingkungan, Motivasi Belajar, Pendidikan Sekolah

\section{Pendahuluan}

Pendidikan merupakan pembekalan kemampuan manusia untuk menyesuaikan diri dengan keadaan di masa depan. Pendidikan memiliki tugas menghasilkan sumber daya manusia (SDM) yang berkualitas bagi kepentingan pembangunan bangsa dan negara. Selain itu, pendidikan juga berperan penting dalam rangka mensejahterakan kehidupan manusia dan meningkatkan kemajuan suatu negara.

Tujuan pendidikan nasional akan dapat dicapai bila didukung oleh seluruh lapisan masyarakat. Pemerintah memiliki banyak cara untuk mewujudkan tercapainya tujuan pendidikan nasional termasuk 
menyediakan wadah pelatihan- pelatihan bagi pendidik untuk meningkatkan kompetensi mengajar pendidik, tidak hanya bagi pendidik pemerintah juga memberikan kemudahan bagi peserta didik yang memasuki jenjang sekolah mulai dari jenjang SD, SMP, SMA, dan Perguruan Tinggi melalui bantuan BOS, kartu pintar dan program - program beasiswa lainnya.

Unsur-unsur pendidikan terdiri dari pertama, peserta didik yaitu orang yang sedang tumbuh dan berkembang dalam segi jasmani dan rohani. setiap individu memiliki potensi berbeda dalam perkembangannya. Perbedaan individu dibedakan menjadi perbedaan fisik, sosial, kepribadian, dan intelegensi. Permasalahan anak didik meliputi sifat kepribadian, kemampuan anak didik, bentuk kegiatan, dan situasi lingkungan dan pengalaman perserta didik.

Kedua, Pendidik yaitu semua pihak yang dapat membantu perkembangan pertumbuhan anak didik dalam mewujudkan tujuan pendidikan nasional. Orangtua menjadi pendidik bagi anak-anaknya yang berfungsi mengasuh, mengasihi, melindungi dan mengasah. Guru menjadi pendidik dengan fungsi mengarahkan dan mencerdaskan peserta didik yang bertanggung jawab terhadap nilai-nilai budi pekerti dari ilmu yang diajarkan.

Ketiga, alat pendidikan. Keempat, Lingkungan pendidikan meliputi lingkungan keluarga, lingkungan sekolah dan lingkungan masyarakat. Kelima, tujuan pendidikan. Dan keenam, interaksi edukatif.

Ngalim Purwanto, berdasarkan kutipan dari Syafril, menyatakan bahwa
"Lingkungan (environment) meliputi semua kondisi dalam dunia ini yang dengan cara tertentu mempengaruhi tingkah laku kita, pertumbuhan, perkembangan atau life process kita

Menurut Wens Tanlain yang dikutip oleh Hasbullah bahwa pada dasarnya lingkungan mencakup:

a. Tempat (lingkungan fisik) :keadaan iklim, keadaan tanah, keadaan alam.

b. Kebudayaan (lingkungan budaya): dengan warisan budaya tertentu bahasa, seni, ekonomi, ilmu pengetahuan, pandangan hidup,keagamaan.

c. Kelompok hidup bersama (lingkungan sosial atau masyarakat), keluarga, kelompok bermain, desa, perkumpulan.

Pada umumnya lingkungan ada tiga yaitu pertama, lingkungan keluarga. Kedua, lingkungan sekolah. Ketiga, lingkungan masyarakat . ketiga lingkungan ini sering disebut dengan tripusat lingkungan.

Lingkungan sekolah mempengaruhi motivasi belajar peserta didik, motivasi sangat diperlukan dalam suatu kegiatan belajar untuk mencapai tujuanpendidikan. Motivasi merupakan suatu energi kuat didalam diri individu untuk melakukan sesuatu secara sungguh-sungguh dan juga keadaan yang memberi dorongan kepada seseorang untuk melakukan suatu kegiatan guna mencapai tujuan.Lingkungan sekolah sangat berperan dalam mencapai tujuan pembelajaran. 
Lingkungan sekolah diusahakan baik dan nyaman bagi peserta didik, dengan lingkungan sekolah yang nyaman dapat membantu konsentrasi belajar peserta didik. Kemudian lingkungan yang baik akan mempengaruhi motivasi belajar peserta didik sehingga prestasi akademiknya akan meningkat.

Terkait dengan hal tersebut, berdasarkan pra penelitian yang penulis lakukan di sekolah SMA Negeri 1 Sayurmatinggi beberapa peserta didik tidak memperhatikan guru karena ada peserta didik yang membuat keributan pada saat kegiatan belajar mengajar, dan jika diperingatkan oleh guru terkadang peserta didik tidak merasa bersalah.

Dari segi kedisiplinan berpakaian terdapat peserta didik yang tidak sesuai dengan peraturan sekolah yang berlaku. Terkadang dalam proses pembelajaran guru tidak menggunakan metode yang menarik untuk peserta didik. Dengan keadaan lingkungan sekolah tersebut motivasi belajar peserta didik akan menurun. Motivasi dalam proses pembelajaran sangat diperlukan dalam menentukan tercapainya prestasi yang optimal.

Dengan tidak adanya motivasi belajar, proses pembelajaran di lingkungan sekolah tidak akan berjalan maksimal yang mengakibatkan prestasi belajar peserta didik otomatis akan menurun.

Untuk mengatasi masalah tersebut, perlu di upayakan sebuah inovasi dalam pembelajaran yaitu dengan jalan guru harus memiliki standar kualitas pribadi tertentu baik di lingkungan sekolah maupun di luar lingkungan sekolah. mewujudkan peran guru tidak hanya sebagai pendidik tetapi juga sebagai pengganti orang tua peserta didik di sekolah. Pemberian motivasi terhadap peserta didik dapat mendorong terbentuknya disiplin ilmu. Dan disiplin ilmu akan membuat peserta didik lebih giat dalam belajar.

Guru sangat berperan dalam memfasilitasi peserta didik dalam proses pembelajaran agar peserta didik termotivasi dalam belajar. Hal ini menuntut guru agar lebih kreatif dalam menyediakan materimateri pembelajaran agar peserta didik lebih termotivasi dalam belajar dan meningkatkan prestasi peserta didik.

Berdasarkan hal tersebut peneliti dalam kesempatan ini terdorong untuk melakukan penelitian dengan judul "Peranan Lingkungan Pendidikan Sekolah Terhadap Motivasi Belajar Bidang Studi Ekonomi Pada Materi Pokok Pendapatan Nasional Peserta Didik Di Kelas X Sma Negeri 1 Sayurmatinggi Tahun Pelajaran 2016-2017"

\section{Metode Penelitian}

Untuk menjawab perumusan masalah penelitian yang telah di uraikan, penulis menggunakan pendekatan yaitu melalui metode penelitian :

\section{Penelitian Kepustakaan (Library Research)}

Penelitian kepustakaan adalah penelitian melalui pengumpulan data tertulis yang bersumber dari sepertibuku, bulletin, koran, dan sumber-sumber lainnya yang 
berkaitan dengan variabel penelitian yang akan di bahas dan diteliti.

\section{Penelitian Lapangan}

Penelitian lapangan adalah penelitian yang hasil datanya bersifat nyata yang diperoleh melalui penyebaran angket secara langsung ke lokasi penelitian yaitu SMA Negeri 1 Sayurmatinggi.

Penulis memilih penelitian asosiatif yang menjadi jenis penelitian dalam penelitian ini. Yakni untuk menjelaskan dan menggambarkan kedua variabel, serta melibatkan peranan diantara kedua variabel tersebut.

\section{Pembahasan dan Hasil}

Data-data yang disajikan dalam pembahasan penelitian ini ada dua variabel penelitian, yaitu peranan lingkungan pendidikan sekolah sebagai variabel (X) Terhadap Motivasi Belajar Bidang Studi Ekonomi Pada Materi Pokok Pendapatan Nasional Peserta Didik Di Kelas X SMA Negeri 1 Sayurmatinggi Tahun Pelajaran2016-2017 sebagai variabel (Y).

Berdasarkan hasil penelitian yang penulis lakukan di kelas X SMA Negeri 1 Sayurmatinggi tahun pelajaran 2016-2017, data yang disebarkan melalui angket, penulis mengklasifikasikan pembobotan nilai sebagai berikut:

a. Apabila peserta didik menjawab Ya maka diberi skor 3 .

b. Apabila peserta didik menjawab Kadang-kadang maka diberi skor 2. c. Apabila peserta didik menjawab Tidak maka diberi skor 1 .

Untuk mencari persentase jawaban angket responden digunakan rumus persentase:

$$
\mathrm{P}=\frac{F}{N} \times 100 \%
$$

Keterangan :

$$
\begin{aligned}
\mathrm{P}= & \begin{array}{l}
\text { Persentase jawaban yang dijawab } \\
\text { responden }
\end{array} \\
\mathrm{F}= & \text { Frekuensi yang dijawab } \\
& \begin{array}{l}
\text { responden terhadap opsi yang } \\
\text { ditawarkan }
\end{array} \\
\mathrm{N}= & \text { Jumlah sampel }
\end{aligned}
$$

Tabel 1

Apakah anda datang ke sekolah tepat waktu ?

\begin{tabular}{|c|l|c|c|}
\hline No & $\begin{array}{l}\text { Alternative } \\
\text { jawaban }\end{array}$ & $\mathbf{F}$ & $\begin{array}{c}\mathbf{P}= \\
\mathbf{F}\end{array}$ \\
\hline \multirow{2}{*}{1.} & $\begin{array}{l}\text { Ya } \\
\text { Kadang- } \\
\text { kadang }\end{array}$ & 16 & 66,66 \\
\cline { 2 - 4 } & Tidak & 9 & 12 \\
\hline \multicolumn{2}{|c|}{ Jumlah } & $\mathbf{7 5}$ & $\mathbf{1 0 0}$ \\
\hline
\end{tabular}

Dari jawaban diatas dapat disimpulkan bahwa peserta didik datang ke sekolah tepat waktu. Hal ini terlihat dari jawaban yang diberikan, yaitu yang menjawab Ya 50 peserta didik $(66,66 \%)$, yang menjawab Kadang-kadang sebanyak 16 peserta didik $(21,33 \%)$, yang menjawab Tidak 9 peserta didik $(12 \%)$. 
Tabel 2

Apakah anda masuk kedalam kelas sebelum guru datang ?

\begin{tabular}{|c|c|c|c|}
\hline No & $\begin{array}{c}\text { Alternative } \\
\text { jawaban }\end{array}$ & $\mathbf{F}$ & $P=\frac{F}{N} \times 100 \%$ \\
\hline \multirow{3}{*}{2.} & $\mathrm{Ya}$ & 41 & 54,66 \\
\hline & $\begin{array}{l}\text { Kadang- } \\
\text { kadang }\end{array}$ & 24 & 32 \\
\hline & Tidak & 10 & 13,33 \\
\hline & Jumlah & 75 & 100 \\
\hline
\end{tabular}

Dari jawaban diatas dapat disimpulkan bahwa peserta didik masuk kedalam kelas sebelum guru datang. Hal ini terlihat dari jawaban yang diberikan, yaitu yang menjawab Ya 41 peserta didik (54,66\%), yang menjawab Kadang-kadang sebanyak 24 peserta didik (32\%), yang menjawab Tidak 10 peserta didik $(13,33 \%)$.

Dari hasil perhitungan koefisien korelasi tersebut maka diperoleh hasil $\mathrm{r}_{\text {hitung }}$ $=0,887$. Dalam hal ini penulis berpatokan pada ketentuan jika $r_{\text {hitung }}>r_{\text {tabel }}$ maka $\mathrm{H}_{\mathrm{a}}$ diterima dan $\mathrm{H}_{\mathrm{o}}$ ditolak, dimana $\mathrm{r}_{\text {tabel }}$ dengan taraf kesalahan 5\% diperoleh sebesar 0,227. Maka diketahui $r_{\text {hitung }}$ lebih besar dari pada $r_{\text {tabel }}$ yaitu $0,887>0,227$.

Berdasarkan perhitungan diatas, dapat disimpulkan bahwa hipotesis dapat diterima. Artinya bahwa "Ada Peranan Lingkungan Pendidikan Sekolah Terhadap Motivasi Belajar Bidang Studi Ekonomi Pada Materi Pokok Pendapatan Nasional Peserta Didik di Kelas X SMA Negeri 1 Sayurmatinggi Tahun Pelajaran 2016-2017”.

\section{Kesimpulan}

Berdasarkan hasil pengolahan data dan penganalisaan data yang dilakukan yang dapat disimpulkan dari hasil penelitian yang dilakukan sebagai berikut:

1. Hasil jawaban respon den penelitian terhadap angket Lingkungan Pendidikan Sekolah diketahui jawaban responden yang menjawab Ya keseluruhan ada 581 jawaban, Kadang-kadang keseluruhan sebanyak 339 jawaban, dan yang menjawab Tidak keseluruhan sebanyak 205 jawaban. Dan yang keseluruhannya terdiri dari 15 butir pertanyaandan 75 pesertadidik. Dengan demikian dapat disimpulkan bahwa responden lebih banyak menjawab Ya. Adapun nilai ratarata dari seluruh jawaban responden sebesar 34,93

2. Hasil jawaban responden penelitian terhadap test Motivasi Belajar Bidang Studi Ekonomi Pada Materi Pokok Pendapatan Nasional Di Kelas X SMA Negeri 1 Sayur matinggi Tahun Pelajaran 2016-2017 diketahui dari jawaban responden nilai tertinggi 93,33 dan nilai terendah 60 , dan nilai rata-rata dari seluruh jawaban responden sebesar 75,73 .

3. Berdasarkan analisis yang dilakukan diperoleh hasil $r_{\text {hitung }}=0,887$ hasil ini kemudian dibandingkan dengan $r_{\text {table }}$ dimana $r_{\text {tabel }}$ diperoleh sebesar 0,227 dengan taraf kesalahan 5\% maka diketahui $r_{\text {hitung }}$ lebih besar daripada $r_{\text {tabel }}$ yaitu $0,887>0,227$ maka dapat 
dikatakan ada Peranan Lingkungan Pendidikan Sekolah Terhadap Motivasi Belajar Bidang Studi Ekonomi Pada Materi Pokok Pendapatan Nasional Peserta Didik Di Kelas X SMA Negeri 1 Sayurmatinggi Tahun Pelajaran 20162017. Maka hipotesis alternative $\left(\mathrm{H}_{\mathrm{a}}\right)$ diterima dan $\left(\mathrm{H}_{\mathrm{o}}\right)$ ditolak.

\section{Saran}

Berdasarkan kesimpulan dan implikasi hasil penelitian di atas, maka yang menjadi saran penulis adalah sebagai berikut:

1. Kepada Kepala Sekolah, diharapkan lebih memperhatikan sarana dan prasarana yang dibutuhkan peserta didik dalam menunjang suksesnya proses belajar di sekolah.

2. Kepada Guru yang mengajar bidang studi ekonomi, diharapkan menggunakan strategi belajar yang tepat supaya dapat memotivasi peserta didik untuk lebih giat dalam belajar.

3. Kepada peserta didik agar tidak pernah bosan maupun jenuh dalam mengikuti pembelajaran di lingkungan pendidikan sekolah.

\section{Daftar Pustaka}

Abdul Kadir, 2012, dasar- dasar pendidikan, Jakarta: Kencana

Ahmad D. Marimba. 2003. Pengantar Filsafat Pendidikan Islam. Bandung: PT. Al-Ma'arif
Arikunto,Suharsimi. 2010. Prosedur Penelitian Suatu Pendekatan Praktik. Jakarta:Rineka Cipta

Bagong Suyanto,2005, Metode Penelitian Sosial, Jakarta ,:kencana

Burhan Bungin, metodologi penelitian kuantitatif, Jakarta:kencana,

Darajat,Zakiyah.2008, Ilmu

Pendidikan Islam, Jakarta:Bumi Aksara

Dimyati, dan Mudjiono. 2009. Belajar Dan Pembelajaran. Jakarta:Rineka Cipta

Din Wahyudin,dkk. 2011. Pengantar Pendidikan. Jakarta:Universitas Terbuka

Djamarah, Syaiful Bahri. 2013. Psikologi belajar. Jakarta:Rineka Cipta

Hamzah B. Uno,2008, Teori Motivasi Dan Pengukurannya, Jakarta:Bumi Aksara,

Hasbullah. 2009. Dasar-Dasar Ilmu Pendidikan. Jakartsa:RajaGrafindo Persada 